\title{
PENYULUHAN HUKUM MENGENAI UNDANG-UNDANG NOMOR 21 TAHUN 2007 TENTANG PEMBERANTASAN TINDAK PIDANA PERDAGANGAN ORANG BAGI GURU BIMBINGAN KONSELING DAN SISWA/SISWI SMK/SMA/MA SE-KABUPATEN CIANJUR
}

\author{
Henny Nuraeny \\ Pascasarjana Program Magister Ilmu Hukum dan Fakultas Hukum \\ Universitas Suryakancana \\ E-mail: hennynuraeny28@gmail.com
}

\begin{tabular}{l|l|l} 
Masuk : Maret 2017 & Penerimaan : Maret 2017 & Publikasi : Juni 2017
\end{tabular}

\begin{abstract}
ABSTRAK
Perdagangan orang merupakan pelanggaran harkat dan martabat manusia yang bertentangan dengan hak asasi manusia dan peraturan perundang-undangan. Korban dari tindak pidana perdagangan orang di kabupaten Cianjur salah satunya adalah anak di bawah umur. Pusat Pelayanan Terpadu Perlindungan Perempuan dan Anak (P2TP2A) Kabupaten Cianjur bekerja sama dengan Fakultas Hukum Universitas Suryakancana menyelenggarakan kegiatan dalam upaya pencegahan tindak pidana perdagangan orang. Upaya yang dilakukan untuk mengatasinya salah satunya adalah mensosialisasikan Undang-Undang Nomor 21 Tahun 2007 tentang Pemberantasan Tindak Pidana Perdagangan Orang bagi guru bimbingan konseling dan siswa/siswi supaya lebih memahami pengertian, cara, bentuk, dampak, pencegahan dan sanksi dalam tindak pidana perdagangan orang.
\end{abstract}

Kata Kunci: Perdagangan Orang, Penyuluhan Hukum, Guru dan Siswa/Siswi.

\section{ABSTRACT}

Trafficking is a violation of human dignity that is contrary to human rights and legislation. One of the victims of the crime of trafficking in the district of Cianjur is underage child. An Integrated Service Center for Women and Children Protection (P2TP2A) of Cianjur district in collaboration with the Faculty of Law of Suryakancana University conducting an even in preventing the human trafficking crime. One of the efforts to overcome the trafficking is by socialize the law No. 21 of 2007 on the Eradication of Trafficking for the counseling teacher and student in order to get a better understanding of the meaning, way, form, effects, prevention and sanction the crime of trafficking.

Keywords: Trafficking, Legal Education, Teacher and Student.

A. PENDAHULUAN

1. Latar Belakang

Perdagangan orang/Trafficking

memuat aspek-aspek yang

bertentangan dengan perlindungan

dan juga berlawanan dengan

kesejahteraan umum. Lebih-lebih praktek trafficking selalu disertai dengan berbagai tindak ancaman dan kekerasan, sehingga menimbulkan ketersiksaan bagi si korban pa masa depannya, apalagi korban trafficking pada umumnya adalah pihak yang dalam kondisi tidak 
berdaya baik secara fisik (perempuan dan anak-anak), psikis, maupun ekonomi. Perdagangan orang merupakan pelanggaran harkat dan martabat manusia.

Ada beberapa faktor yang melatarbelakangi terjadinya perdagangan manusia diantaranya adalah kemiskinan, daya tarik standar hidup di tempat lain yang dirasakan lebih tinggi, lemahnya struktur sosial dan ekonomi, kurangnya kesempatan kerja, kejahatan yang terorganisir, kekerasan terhadap wanita dan anak-anak, diskriminasi terhadap wanita, kurang kewaspadaan korban untuk mendapatkan pekerjaan, kultur yang menempatkan wanita pada tingkat yang lebih rendah, kurangnya keamanan aparat penegak hukum dalam penjagaan daerah perbatasan serta minimnya perhatian pemerintah. Selain itu, kurangnya pendidikan yang bersifat menyeluruh, yang terutama meliputi pendidikan dalam ilmu pengetahuan, pendidikan moral, pendidikan agama, dan pendidikan kewarganegaraan.

Praktik perdagangan orang (trafficking) di wilayah Kabupaten Cianjur merupakan masalah yang krusial. Berdasarkan hasil survey, Kabupaten Cianjur dikategorikan sebagai wilayah yang dikategorikan rawan praktik perdagangan orang meliputi daerah Cianjur selatan dan Cianjur Utara. Korban perdagangan orang meliputi anak di bawah umur dan dewasa baik perempuan maupun laki-laki.

Merujuk dari pernyataan di atas, sosialisasi Undang-Undang Nomor 21 Tahun 2007 tentang Pemberantasan Tindak Pidana perdagangan orang sangat penting sekali dilakukan dalam rangka meningkatkan pemahaman masyarakat tentang perdagangan orang serta mencegah terjadinya perdagangan orang.

Berdasarkan hal tersebut di atas maka penulis melaksanakan pengabdian pada masyarakat bekerjasama dengan Pusat Pelayanan Terpadu Perlindungan Perempuan dan Anak (P2TP2A) Kabupaten Cianjur dalam kegiatan yang berjudul "PENYULUHAN HUKUM TENTANG UNDANGUNDANG NOMOR 21 TAHUN 2007 TENTANG PEMBERANTASAN TINDAK PIDANA PERDAGANGAN ORANG BAGI GURU BIMBINGAN KONSELING \& SISWA/SISWI SMK/SMA/MA SE-KABUPATEN CIANJUR". Mensosialisasikan peraturan yang berkaitan dengan perdagangan orang di Kabupaten Cianjur banyak sekali permasalahannya, oleh karena itu penulis hanya membatasi pada hal-hal sebagai berikut:

a. Materi apa saja yang disampaikan dalam kegiatan sosialisasi Undang-Undang Nomor 21 Tahun 2007 tentang Pemberantasan Tindak Pidana Perdagangan Orang kepada para guru dan siswa/siswi?

b. Bagaimanakah respon para guru \&siswa/siswi terhadap kegiatan penyuluhan hukum UndangUndang Nomor 21 Tahun 2007 tentang Pemberantasan Tindak Pidana Perdagangan Orang (Trafficking)?

\section{Lokasi Pengabdian}

Penyuluhan ini dilaksanakan dalam tiga wilayah yakni di SMA Cianjur Selatan, Cianjur Kota (SMANSA Cianjur) dan Cianjur Utara (SMKN I Pacet) pada Bulan Maret 2016. 


\section{Peserta}

Peserta kegiatan tersebut dihadiri tidak kurang dari 150 (seratus lima puluh) orang di setiap wilayah.

\section{B. METODE}

$\mathrm{Di}$ dalam penulisan artikel ini menggunakan metode pendekatan yuridis normatif, dengan spesifikasi penelitian yaitu deskriptif analisis. Lokasi pengabdian pada masyarakat ini dilakukan di Kabupaten Cianjur.

\section{HASIL/PEMBAHASAN}

1. Materi Penyuluhan Hukum

Pembukaan Undang-Undang Dasar 1945 mengamanatkan bahwa negara dan pemerintah didirikan untuk melindungi segenap bangsa dan tanah tumpah darah Indonesia, mencerdaskan kehidupan bangsa, dan kesejahteraan umum. ${ }^{1}$

Sementara perdagangan orang memuat aspek-aspek yang bertentangan dengan perlindungan dan juga berlawanan dengan kesejahteraan umum. Lebih-lebih praktek perdagangan orang selalu disertai dengan berbagai tindak ancaman dan kekerasan, sehingga menimbulkan ketersiksaan bagi si korban pada masa depannya, apalagi korban perdagangan orang pada umumnya adalah pihak yang dalam kondisi tidak berdaya baik secara fisik (perempuan dan anakanak), psikis, maupun ekonomi.

Makna Pembukaan UUD 1945 di atas, menegaskan tentang pentingnya menciptakan suatu kesejahteraan umum dalam negara (welfare state). Untuk memajukan kesejahteraan umum tersebut, mutlak dibutuhkan sarana ketertiban sosial, yang merujuk pada upaya menciptakan aman, tertib dan damai, yang salah

Baca UUD 1945 Amandemen kedua satunya melalui sarana hukum (terutama penegakan hukum). Hukum yang berfungsi imperatif sebagai sarana kontrol sosial diwujudkan dalam sanksi-sanksinya, yang berkolerasi antara penerapan hukum sebagai kebijakan hukum, khususnya hukum pidana yang dilakukan melalui kebijakan kriminal (criminal policy) dan kebijakan sosial (social policy). Selain itu UUD 1945 Amandemen kedua Pasal 28 A-J telah memberikan jaminan atas Hak Asasi Manusia (HAM), yang kemudian dipertegas dalam Undang-Undang Nomor 39 Tahun 1999 tentang Hak Asasi Manusia.

Negara Indonesia sebagai negara hukum, maka dalam menjalankan segala kehidupan bernegara harus sesuai dengan aturan hukum yang berlaku demi terciptanya suatu ketertiban hukum dalam masyarakat. Hal ini sesuai dengan istilah Negara Indonesia adalah Negara hukum (Rechstaat) yang berdasarkan pada Pancasila. ${ }^{2}$ Indonesia sebagai Negara hukum telah tergambar jelas dalam UUD 1945. Salah satu esensi Negara hukum adalah ditampilkannya peranan hukum secara mendasar sebagai titik sentral dalam kehidupan ketatanegaraan dan kemasyarakatan menuju kehidupan yang adil dan sejahtera. Untuk itu komponen-komponen pokok dari sistem hukum perlu diperkokoh sebagai pilar utama dalam penegakan hukum. ${ }^{3}$ Tujuan yang hendak dicapai Negara Indonesia adalah terwujudnya masyarakat

\footnotetext{
Dedi Mulyadi, (2012), Kebijakan Legislasi tentang Sanksi Pidana Pemilu Legislatif di Indonesia dalam Perspektif Demokrasi, Jakarta, Gramata Publishing, hlm. 19.

T. Subarsyah Sumadikara, (2010), Penegakan Hukum (Sebuah Pendekatan Politik Hukum dan Politik Kriminal), TT, Kencana Utama, hlm. 16.
} 
yang adil dan makmur baik spiritual maupun material berdasarkan Pancasila. ${ }^{4}$

Gejala sosial dalam masyarakat dapat berbagai macam bentuk dan latar belakangnya. Salah satu gejala sosial yang berupa pelanggaran hukum HAM, adalah perdagangan orang, karena itu pencegahan terhadap Tindak Pidana Perdagangan Orang (TPPO) harus didasarkan pada hukum HAM yang tujuannya untuk menciptakan ketertiban, keadilan dan kesejahteraan masyarakat. Upaya untuk melakukan pencegahan terhadap TPPO merupakan suatu strategis sosial karena itu diperlukan kebijakan kriminal yang tujuannya adalah untuk mengurangi kejahatan dan memenuhi rasa keadilan masyarakat. ${ }^{5}$

Di dalam Pasal 1 angka 1 UndangUndang Nomor 21 Tahun 2007 tentang Pemberantasan Tindak Pidana Perdagangan Orang (PTPPO), Perdagangan orang didefinisikan sebagai tindakan perekrutan, pengangkutan, penampungan, pengiriman, pemindahan, atau penerimaan seseorang dengan ancaman kekerasan, penggunaan kekerasan, penculikan, penyekapan, pemalsuan, penipuan, penyalahgunaan kekerasan atau posisi rentan, penjeratan utang, atau memberi bayaran, atau manfaat sehingga memperoleh persetujuan dari orang yang memegang kendali atas orang lain tersebut, baik yang dilakukan dalam Negara maupun antar Negara untuk tujuan eksploitasi atau

\footnotetext{
4 Lilik Mulyadi, (2007), Pembalikan Beban Pembuktian Tindak Pidana Korupsi, Alumni, Bandung, hlm. 64.

Henny Nuraeny, (2011), Kebijakan Hukum Pidana terhadap Pencegahan Tindak Pidana Perdagangan Orang, Jakarta, Sinar Grafika, hlm. 149 .
}

mengakibatkan orang tereksploitasi. Perdagangan orang selalu memiliki 3 (tiga) unsur dasar:

a. Proses: Pertama, biasanya pelaku memindahkan korban jauh dari komunitasnya dengan merekrut, mengangkut, mengirim, memindahkan atau menerima mereka;

b. Cara: Lalu pelaku menggunakan ancaman, kekerasan, penculikan, penyekapan, pemalsuan, penyalahgunaan kekuasaan/ posisi rentan, atau jeratan hutang untuk mendapat kendali atas diri korban sehingga dapat memaksa mereka;

c. Tujuan: dan pada akhirnya, pelaku mengeksploitasi atau menyebabkan korban tereksploitasi untuk keuntungan financial mereka sendiri. Eksploitasi disini dapat berarti membuat korban bekerja dalam prostitusi, mengurung korban dengan kekerasan fisik atau psikologis (kerja paksa), menempatkan korban dalam situasi jeratan hutang atau bahkan perbudakan. Dalam beberapa kasus, eksploitasi dapat juga berarti pemanfaatan atau transplantasi organ tubuh.

d. Bentuk-bentuk perdagangan orang ialah:

1) Pengiriman Tenaga Kerja Indonesia (TKI) ke luar negeri tanpa adanya dokumen resmi atau dengan dokumen yang dipalsukan dan dengan berkedok berbagai kegiatan legal, misalnya "misi kebudayaan".

2) Penempatan tenaga kerja di dalam negeri untuk di eksploitasi secara seksual.

3) Penyelenggaraan perkawinan berbatas waktu (kawin kontrak). 
4) Prostitusi.

Ada empat hal sifat dasar perdagangan orang, yaitu: Bersifat manipulatif atau penyalahgunaan; Adanya transaksi; Tidak mengerti; dan Ada migrasi.

Tindak pidana perdagangan orang umumnya dilakukan dengan cara pelanggaran terhadap hak asasi manusia, yaitu berupa pelanggaran harkat dan martabat manusia yang berupa perlakuan kejam, dan bahkan perlakuan serupa perbudakan. Perlakuan ini diterima sebagai ketidakberdayaan korban, yang terjebak dalam jeratan jaringan yang sangat sulit untuk diidentifikasi, sehingga akan berakibat sulit untuk menemukan solusinya.

Faktor-faktor yang paling mendukung adanya perdagangan orang diantaranya karena adanya permintaan (demand) terhadap pekerjaan di sektor informal yang tidak memerlukan keahlian khusus, mau dibayar dengan upah relatif rendah serta tidak memerlukan perjanjian kerja yang rumit, sehingga menyebabkan para trafficker terdorong untuk melakukan bisnis trafficking. Dari segi ekonomi kegiatan usaha/bisnis seperti ini dapat mendatangkan keuntungan yang sangat besar serta adanya celah hukum yang menguntungkan para trafficker yaitu kurangnya penegakan hukum di Indonesia, terutama dalam mengadili pelaku perdagangan orang, termasuk pemilik/pengelola/perusahaan

pengerah tenaga kerja, sehingga mereka dapat memanfaatkan korban dan calon korban perdagangan orang.

Para pelaku perdagangan orang bekerja sangat rapi dan terorganisasi. Umumnya mereka melakukan pencarian korban dengan berbagai cara, seperti mengimingimingi calon korban dengan berbagai daya upaya. Dari berbagai kejadian dalam TPPO, kerugian dan penderitaan korban disebabkan oleh adanya proses: Perekrutan, pemalsuan dokumen, penyekapan sebelum berangkat, pengangkutan dalam perjalanan, di tempat kerja, perjalanan ulang, dan pemulihan/rehabilitasi. 6

Indikator TPPO adalah sebagai berikut:

a. Tidak menerima upah (dibayar hanya sejumlah kecil) imbalan bagi pekerjaan yang dilakukannya.

b. Tidak dapat mengelola sendiri upah yang diterima atau harus menyerahkan sebagian besar upahnya kepada pihak ketiga (perantara, agen, majikan, dalam bisnis pelacuran: pengelola rumah bordir, mucikari);

c. Adanya jeratan utang (misalnya saja untuk membayar biaya pengganti rekrutmen, jasa perantara, biaya perjalanan, dII.).

d. Pembatasan atau perampasan kebebasan bergerak (misal tidak boleh meninggalkan tempat kerja atau penampungan untuk jangka waktu lama, di bawah pengawasan terusmenerus).

e. Tidak diperbolehkan (dengan ancaman/kekerasan) berhenti bekerja.

\footnotetext{
6 L.M. Gandhi Lapian dan Hetty A. Geru, (2006), Trafficking Perempuan dan Anak Penanggulangan Komprehensif Studi Kasus: Sulawesi Utara, Kerja sama Yayasan Obor, Convention Watch, Jakarta, Pusat Kajian Perempuan Universitas Indonesia, dan NZAID, hlm. 61-65.
} 
f. Isolasi/pembatasan kebebasan untuk mengadakan kontak dengan orang lain (keluarga, teman, dII.).

g. Ditahan atau tidak diberikan pelayanan kesehatan, makanan yang memadai, dll.

h. Pemerasan atau ancaman pemerasan terhadap keluarga atau anak-anaknya.

i. Ancaman

penggunaan kekerasan.

j. Ditemukan tanda-tanda kekerasan fisik.

k. Diharuskan bekeria dalam kondisi yang sangat buruk dan/ atau harus bekerja untuk jangka waktu yang sangat panjang.

I. Tidak membayar sendiri atau mengurus sendiri perjalanan, visa, paspor, dll.

m. Tidak memegang sendiri suratsurat identitas diri atau dokumen perjalanannya.

n. Menggunakan paspor atau identitas palsu yang disediakan oleh pihak ketiga.

o. Indikator Khusus untuk tujuan eksploitasi Pelacuran:

1) Mendapatkan bagian sangat kecil dari upah yang umumnya dibayarkan dalam bisnis pelacuran.

2) Diharuskan mendapatkan penghasilan dalam jumlah tertentu perhari.

3) Pengelola bordir atau pihak ketiga telah membayar ongkos transfer bagi calon korban dan/atau menyerahkan sebagian penghasilan calon korban kepada pihak ketiga.

4) Tempat di mana calon korban dipekerjakan berubah-ubah. ${ }^{7}$
Atas dasar itu perlu dilakukan berbagai suatu pencegahan, untuk masa kini dan masa yang akan datang, karena pencegahan kejahatan lebih baik dari pada menanggulanginya. Berbagai upaya telah dilakukan, tetapi tujuan utamanya adalah:

a. Tindakan pencegahan lebih baik dari tindakan represif dan koreksi, juga tidak memerlukan birokrasi yang rumit yang menimbulkan penyalahgunaan wewenang/kekuasaan.

b. Upaya pencegahan akan lebih ekonomis dibandingkan dengan usaha represif dan rehabilitasi korban.

c. Upaya pencegahan dapat dilakukan oleh siapa saja, baik perorangan ataupun kelompok.

d. Upaya pencegahan dapat mempererat persatuan, kerukunan, dan meningkatkan rasa tanggung jawab terhadap sesama anggota masyarakat.

e. Upaya pencegahan dapat membantu mengembangkan kehidupan bernegara dalam bermasyarakat yang lebih baik, pada akhirnya dapat tercapai masyarakat yang adil dan makmur.

f. Upaya pencegahan merupakan suatu usaha menciptakan kesejahteraan mental, fisik, dan sosial masyarakat. ${ }^{8}$

Secara umum faktor yang menyebabkan terjadinya TPPO (faktor kriminogen) adalah:

a. Faktor Internal

Hal ini disebabkan karena:

1) Keinginan untuk mencari pengalaman kerja; 
2) Adanya godaan untuk memperoleh penghasilan/gaji yang tinggi;

3) Tidak adanya peluang kerja di daerah asal (umumnya di perdesaan);

4) Pola hidup konsumerisme;

5) Tingkat pendidikan yang rendah (putus sekolah);

6) Perasaan bosan untuk tinggal di daerah asal (perdesaan);

7) Adanya tindak kekerasan dalam rumah tangga;

8) Melihat orang lain yang sukses bekeria di luar daerah (desa asal);

9) Tidak perlu memiliki ketrampilan khusus/ijazah yang tinggi;

10) Adanya dorongan orang tua/keluarga (kebutuhan ekonomi);

11) Adanya permintaan yang tinggi/kesempatan kerja sebagai pembantu rumah tangga perempuan.

b. Faktor Eksternal

Faktor ini datang dari luar diri korban, yaitu:

1) Budaya masyarakat yaitu belum adanya kesetaraan gender (masih bias gender);

2) Lemahnya sistem hukum yang belum mendukung penegakan hukum terhadap TPPO;

3) Kondisi daerah (konflik, bencana alam).

4) Berdasarkan pengertian tersebut, maka korban selalu berhubungan dengan:

a) Individu atau kelompok, baik swasta maupun pemerintah;

b) Tindakan yang diterima oleh korban tidak terbatas pada tindakan yang di atur dalam undang- undang saja, melainkan segala hal yang berhubungan dengan kejahatan, deliquensi, deviasi, dan kejahatan lain yang selalu berubah-ubah sesuai dengan perkembangan waktu, tempat dan jaman, serta pandangan masyarakat yang berhubungan dengan perkembangan sosial, ekonomi, politik dan budaya.

c) Pada umumnya korban selalu menimpa manusia, sehingga sudah sewajarnya apabila korban (dan saksi apabila ada) diperlakukan secara manusiawi, sesuai dengan falsafah Pancasila. 9

Berdasarkan beberapa faktor penyebab dan faktor yang diderita korban, maka sasaran kebijakan hukum pidana yang semula diarahkan kepada perbuatan (crime) sebagai prevention of crime, bergeser kepada orang (offender) dengan sasaran treatment of offender, dan berkembang kepada korban (victim) yang sasarannya treatment of victims. Adanya perhatian terhadap korban, sesuai dengan perkembangan dewasa ini, agar hukum pidana menghapuskan kesan seolah-olah hanya memanjakan pelaku ketimbang korban. ${ }^{10}$

Pada umumnya korban mengalami kerugian baik fisik, psikis, mental dan sosial, sehingga memerlukan bantuan

\footnotetext{
9 Arif Gosita, (2004), Masalah Korban Kejahatan, ... Ibid, hlm. 64.

10 Arief Amarullah, Politik Hukum Pidana Perlindungan Korban Tindak Pidana Perdagangan Orang, Dalam Satya Arinanto \& Ninuk Triyani (Ed), (2009), Memahami Hukum Dari Konstruksi Sampai Implementasi, Jakarta, Raja Grafindo Persada, hlm. 133
} 
dan perlindungan secara seimbang dan manusiawi. Dari sisi korban (victim) faktor yang sering diderita korban TPPO umumnya berupa penderitaan/kerugian materil dan immateril (fisik, psikis, ekonomi dan sosial), yaitu berupa:

a. Kerugian materil. Kerugian ini muncul karena kondisi korban yang berada pada kondisi lemah dari segi ekonomi (kemiskinan), dan tingkat pendidikan yang rendah, maka akan mudah para trafficker untuk melakukan penipuan, pemerasan, pemalsuan, penjeratan utang, dari pemberangkatan sampai pemulangan ke kampung halamannya, dan

b. Kerugian immateril. Kerugian ini lebih banyak dialami korban

Tabel 2.1

Bunyi Pasal 2, Pasal 3, pasal 4, dan Pasal 6

\begin{tabular}{|c|c|c|c|c|}
\hline No & Pasal & Isi Pasal & Ancaman Pidana & Ket \\
\hline 1 & Pasal 2 & $\begin{array}{l}\text { (1) Setiap orang yang melakukan } \\
\text { perekrutan, pengangkutan, penampungan, } \\
\text { pengiriman, pemindahan, atau penerimaan } \\
\text { seseorang dengan ancaman kekerasan, } \\
\text { penggunaan kekerasan, penculikan, penyekapan, } \\
\text { pemalsuan, penipuan, penyalahgunaan } \\
\text { kekuasaan atau posisi rentan, penjeratan utang } \\
\text { atau memberi bayaran atau manfaat walaupun } \\
\text { memperoleh persetujuan dari orang yang } \\
\text { memegang kendali atas orang lain, untuk tujuan } \\
\text { mengeksploitasi orang tersebut di wilayah } \\
\text { negara Republik Indonesia, dipidana dengan } \\
\text { pidana penjara paling singkat } 3 \text { (tiga) tahun dan } \\
\text { paling lama } 15 \text { (lima belas) tahun dan pidana } \\
\text { denda paling sedikit Rp. } 120.000 .000,00 \\
\text { (seratus dua puluh juta rupiah) dan paling banyak } \\
\text { Rp. } 600.000 .000,00 \text { (enam ratus juta rupiah). } \\
\text { (2) Jika perbuatan sebagaimana } \\
\text { dimaksud pada ayat (1) mengakibatkan orang } \\
\text { tereksploitasi, maka pelaku dipidana dengan } \\
\text { pidana yang sama. }\end{array}$ & $\begin{array}{l}\text { Dipidana dengan pidana } \\
\text { penjara paling singkat } 3 \\
\text { (tiga) tahun dan paling } \\
\text { lama } 15 \text { (lima belas) } \\
\text { tahun dan pidana denda } \\
\text { paling sedikit Rp. } \\
120.000 .000,00 \text { (seratus } \\
\text { dua puluh juta rupiah) dan } \\
\text { paling banyak Rp. } \\
\text { 600.000.000,00 (enam } \\
\text { ratus juta rupiah). }\end{array}$ & \\
\hline 2 & Pasal 3 & $\begin{array}{l}\text { Setiap orang yang memasukkan orang ke } \\
\text { wilayah negara Republik Indonesia dengan } \\
\text { maksud untuk dieksploitasi di wilayah negara } \\
\text { Republik Indonesia atau dieksploitasi di negara } \\
\text { lain dipidana dengan pidana penjara paling } \\
\text { singkat } 3 \text { (tiga) tahun dan paling lama } 15 \text { (lima } \\
\text { belas) tahun dan pidana denda paling sedikit Rp. } \\
120.000 .000,00 \text { (seratus dua puluh juta rupiah) } \\
\text { dan paling banyak Rp. } 600.000 .000,00 \text { (enam } \\
\text { ratus juta rupiah). }\end{array}$ & $\begin{array}{l}\text { Dipidana dengan pidana } \\
\text { penjara paling singkat } 3 \\
\text { (tiga) tahun dan paling } \\
\text { lama } 15 \text { (lima belas) } \\
\text { tahun dan pidana denda } \\
\text { paling sedikit Rp. } \\
120.000 .000,00 \text { (seratus } \\
\text { dua puluh juta rupiah) dan } \\
\text { paling banyak Rp. } \\
\text { 600.000.000,00 (enam } \\
\text { ratus juta rupiah). }\end{array}$ & \\
\hline
\end{tabular}




\begin{tabular}{|c|c|c|}
\hline 3 & Pasal 4 & $\begin{array}{l}\text { Setiap orang yang membawa warga negara } \\
\text { Indonesia ke luar wilayah negara Republik } \\
\text { Indonesia dengan maksud untuk dieksploitasi di } \\
\text { luar wilayah negara Republik Indonesia dipidana } \\
\text { dengan pidana penjara paling singkat } 3 \text { (tiga) } \\
\text { tahun dan paling lama } 15 \text { (lima belas) tahun dan } \\
\text { pidana denda paling sedikit Rp. } 120.000 .000,00 \\
\text { (seratus dua puluh juta rupiah) dan paling banyak } \\
\text { Rp. } 600.000 .000,00 \text { (enam ratus juta rupiah). } \\
\text { Kemudian, Pasal } 5 \text { menjelaskan bahwa Setiap } \\
\text { orang yang melakukan pengangkatan anak } \\
\text { dengan menjanjikan sesuatu atau memberikan } \\
\text { sesuatu dengan maksud untuk dieksploitasi } \\
\text { dipidana dengan pidana penjara paling singkat } \\
3 \text { (tiga) tahun dan paling lama } 15 \text { (lima belas) } \\
\text { tahun dan pidana denda paling sedikit Rp. } \\
120.000 .000,00 \text { (seratus dua puluh juta rupiah) } \\
\text { dan paling banyak Rp. } 600.000 .000,00 \text { (enam } \\
\text { ratus juta rupiah). }\end{array}$ \\
\hline 4 & Pasal 6 & $\begin{array}{l}\text { Setiap orang yang melakukan pengiriman anak } \\
\text { ke dalam atau ke luar negeri dengan cara apa } \\
\text { pun yang mengakibatkan anak tersebut } \\
\text { tereksploitasi dipidana dengan pidana penjara } \\
\text { paling singkat } 3 \text { (tiga) tahun dan paling lama } 15 \\
\text { (lima belas) tahun dan pidana denda paling } \\
\text { sedikit Rp. } 120.000 .000,00 \text { (seratus dua puluh } \\
\text { juta rupiah) dan paling banyak Rp. } \\
600.000 .000,00 \text { (enam ratus juta rupiah). }\end{array}$ \\
\hline
\end{tabular}

Dipidana dengan pidana penjara paling singkat 3 (tiga) tahun dan paling lama 15 (lima belas) tahun dan pidana denda paling sedikit Rp. 120.000.000,00 (seratus dua puluh juta rupiah) dan paling banyak $\mathrm{Rp}$. 600.000.000,00 (enam ratus juta rupiah).

Dipidana dengan pidana penjara paling singkat 3 (tiga) tahun dan paling lama 15 (lima belas) tahun dan pidana denda paling sedikit Rp. 120.000.000,00 (seratus dua puluh juta rupiah) dan paling banyak $\mathrm{Rp}$. 600.000.000,00 (enam ratus juta rupiah).

Undang-Undang Nomor 21 Tahun 2007 tentang PTPPO, menyatakan di dalam Pasal 58 bahwa Gugus Tugas PTPPO dibentuk di tingkat nasional, provinsi dan kabupaten/kota di seluruh Indonesia.

Tabel 2.2

Upaya Pemerintah

\begin{tabular}{|c|c|c|}
\hline No & Jenis Pelayanan & Jumlah \\
\hline 1 & $\begin{array}{l}\text { Pemerintah memberikan layanan melalui Pusat Pelayanan } \\
\text { Terpadu (PPT) berbasis rumah sakit sebagai lembaga } \\
\text { layanan korban kekerasan }\end{array}$ & 123 (seratus dua puluh tiga) \\
\hline 2 & $\begin{array}{l}\text { Pusat Pelayanan Terpadu Pemberdayaan Perempuan dan } \\
\text { Anak (P2TP2A) Provinsi }\end{array}$ & 33 (tiga puluh tiga) \\
\hline 3 & P2TP2A Kabupaten/Kota & $\begin{array}{l}247 \text { (dua ratus empat puluh } \\
\text { tujuh) }\end{array}$ \\
\hline 4 & $\begin{array}{l}\text { Citizen Services di Kedutaan Besar Republik Indonesia } \\
\text { (KBRI) dan Konsulat Jenderal Republik Indonesia (KJRI) }\end{array}$ & 24 (dua puluh empat) \\
\hline 5 & Puskesmas mampu tatalaksana kekerasan terhadap anak & 1.060 (seribu enam puluh) \\
\hline 6 & Rumah sakit rujukan bagi TKI bermasalah & 25(dua puluh lima) \\
\hline 7 & Rumah Perlindungan Trauma Center (RPTC) & 22 (dua puluh dua) \\
\hline 8 & Rumah Perlindungan Sosial Anak (RPSA), & 15 (lima belas) \\
\hline 9 & Rumah Perlindungan Sosial Wanita (RPSW) & 1 (satu) Rumah \\
\hline 10 & $\begin{array}{l}\text { Sejumlah lembaga masyarakat, sejumlah lembaga } \\
\text { bantuan hukum, dan beberapa organisasi perempuan di } \\
\text { tingkat desa }\end{array}$ & - \\
\hline
\end{tabular}
untuk melakukan penanganan terhadap korban TPPO. Upaya pemerintah tersebut dapat dilihat dalam tabel di bawah ini:

Pemerintah terus berupaya 
Strategi pencegahan dan penanganan TPPO adalah:

a. Meningkatkan pemahaman masyarakat dan aparat tentang isu TPPO dan Dampaknya;

b. Meningkatkan peran serta masyarakat, dan penguatan lembaga keagamaan dan kemasyarakatan;

c. Mengembangkan jejaring dan kemitraan dg NGO Lokal, Lembaga Internasional, Perguruan Tinggi, dsb;

d. Meningkatkan peran Gugus Tugas PP-TPPO;

e. Mengembangkan kerjasama antar Pusat dan Daerah dalam mengimplementasikan kebijakan;

f. Memperkuat lembaga layanan baik yang berbasis Pemerintah maupun berbasis masyarakat.

Melihat pada beberapa kasus TPPO yang terjadi, maka kendala dalam upaya pencegahan tindak pidana perdagangan orang sangat beragam dan kompleks karena penyebab dari tindak pidana perdagangan orang pun beragam modusnya. Diantara kendala tersebut yang paling signifikan adalah:

a. Masih banyak anggota masyarakat yang hidup di bawah garis kemiskinan;

b. Minimnya kualitas pendidikan dan pelatihan bagi calon TKI yang akan bekerja ke luar negeri;

c. Masih minimnya sarana perekrutan tenaga kerja lokal;

d. Masih adanya pemahaman dalam masyarakat untuk melegalkan perkawinan usia dini;

e. Masih maraknya penjeratan hutang dalam perekrutan sampai pemulangan tenaga kerja sehingga berpotensi TPPO;

f. Masih kurangnya kegiatan pendukung di daerah asal korban TPPO, sehingga korban yang sudah dipulangkan rentan untuk diperdagangkan kembali;

g. Masih ada pemanfaatan fasilitas wisata untuk membuka celah prostitusi;

h. Belum optimalnya peran serta masyarakat dan tokoh masyarakat dalam upaya penanggulangan TPPO;

i. Belum ada sistem monitoring dan evaluasi yang terpadu dalam pencegahan TPPO;

j. Belum adanya pemahaman yang sama dalam penegakan hukum TPPO;

k. Instrumen hukum yang menyulutkan dalam menghadirkan alat bukti;

I. Lemahnya keterlibatan masyarakat dalam upaya pencegahan dan penindakan pelaku;

m. Kualitas SDM aparat penegak hukum dan sarana serta prasarana yang belum mendukung;

n. Masih lemahnya bantuan hukum bagi korban terutama korban yang bekerja di luar negeri;

o. Terdapat kesulitan dalam teknis penanganan pelaku yang berstatus WNA;

p. Belum optimalnya peran dan fungsi gugus tugas di tingkat nasional, propinsi dan kabupaten/kota;

q. Masih lemahnya koordinasi subgugus tugas TPPO dan ESA dalam penanganan korban;

r. Masih minimnya data akurat korban TPPO karena korban baru melapor apabila ada kerugian/penderitaan (fisik, psikis dan ekonomi);

s. Masih ada kendala dalam penanganan rehabilitasi dari korban TPPO;

t. Masih ada kendala dalam proses birokrasi dalam 
penanganan korban, sehingga dapat menghambat pencegahan dan penegakan hukum;

u. Belum optimalnya penyediaan anggaran dari pemerintah terhadap penanganan korban terutama pemulangan bagi korban yang ada di luar negeri; dan

v. Masih lemahnya landasan hukum bagi perwakilan negara Indonesia di luar negeri dalam upaya penanganan pekerja migran di negara tujuan. ${ }^{11}$

\section{Respon Masyarakat Terhadap Kegiatan Penyuluhan Hukum}

Konsep hukum pembangunan yang awalnya berasal dari pemikiran Roscoe Pound, dimana hukum berfungsi sebagai alat rekayasa masyarakat, langkah yang diambil dalam social engineering menurut Satjipto Raharjo harus bersifat sistematis, yang diawali dari identifikasi problem sampai jalan pemecahannya, yaitu:

a. Mengenali problem yang dihadapi sebaik-baiknya. Termasuk di dalamnya mengenali seksama masyarakat yang hendak menjadi sasaran dari penggarapan tersebut;

b. Memahami nilai-nilai yang ada dalam masyarakat. Hal ini penting kalau social engineering itu hendak diterapkan pada masyarakat dengan sektorsektor kehidupan majemuk, seperti; tradisional, modern dan perencanaan. Pada tahap ini ditentukan nilai-nilai dari sektor mana yang dipilih;

\footnotetext{
11 Program kerja dan kegiatan gugus tugas berdasarkan PERMENKO Bidang kesejahteraan Rakyat No. 25/KEP/MENKO/KESRA/IX/2009.
}

c. Membuat hipotesis-hipotesis dan memilih mana yang paling layak untuk dilaksanakan; dan

d. Mengikuti jalannya penerapan hukum dan mengukur efekefeknya. ${ }^{12}$

Kegiatan penyuluhan hukum dan sosialisasi peraturan perundangundangan sangat penting sekali. Sosialisasi dibagi menjadi dua: sosialisasi primer (dalam keluarga) dan sosialisasi sekunder (dalam masyarakat). Menurut Goffman kedua proses tersebut berlangsung dalam institusi total, yaitu tempat tinggal dan tempat bekerja. Dalam kedua institusi tersebut, terdapat sejumlah individu dalam situasi yang sama, terpisah dari masyarakat luas dalam jangka waktu kurun tertentu, bersama-sama menjalani hidup yang terkungkung, dan diatur secara formal. ${ }^{13}$

Pada kegiatan sosialisasi penanganan korban perdagangan orang ada beberapa kendala yang dihadapi oleh penulis, yaitu pendekatan kepada pemerintah dan masyarakat serta masih minimnya pengetahuan peserta sosialisasi sehingga penulis harus lebih rinci dan memperjelas dengan berbagai contoh kejadian secara berulangulang.

Tujuan dari kegiatan pengabdian kepada masyarakat ini adalah mendukung Program Perguruan Tinggi untuk berpartisipasi dalam usaha mencegah terjadinya perdagangan orang melalui kegiatan penyadaran. Selain itu juga untuk menyebarluaskan informasi

\footnotetext{
12 Henny Nuraeny, (2011), Tindak Pidana Perdagangan Orang, Kebijakan Hukum Pidana dan Pencegahannya, Cetakan Pertama, Sinar Grafika, Jakarta, hlm. 150.

13 Wikipedia Bahasa Indonesia, diunduh tanggal 18 Agustus 2015.
} 
pada masyarakat dan keluarga, sebagai bagian anggota masyarakat, mengenai tanggung jawab/peran aktif masyarakat dalam upaya pencegahan terjadinya perdagangan orang dan ikut menangani korban perdagangan orang tersebut.

Di dalam mengatasi permasalahanpermasalahan yang timbul pada saat sosialisasi tentang tindak pidana perdagangan orang, penulis melakukan dengan upaya-upaya sebagai berikut:
a. Jadwal sosialisasi mengikuti jadwal kegiatan di Pemerintah Daerah.

b. Sosialisasi di masyarakat dilakukan dengan cara memasukkan ke dalam acara rutin;

c. Membuat Buku saku..

d. Metode ceramah dan tanya jawab.

Pelaksanaan kegiatan penyuluhan hukum/sosialisasi tersebut sangat lancar, para peserta sangat antusias sekali terkait materi perdagangan orang yang disampaikan oleh para narasumber.

\section{PENUTUP}

1. Kesimpulan

Berdasarkan uraian di atas, maka penulis dapat menarik kesimpulan sebagai berikut:

a. Materi sosialisasi Undang-

Undang Nomor 21 Tahun 2007

tentang Pemberantasan Tindak

Pidana Perdagangan Orang

bagi guru bimbingan konseling

dan siswa/siswi meliputi

pengertian, cara, bentuk, dampak, pencegahan dan sanksi dalam tindak pidana perdagangan orang.

b. Respon peserta sosialisasi sangat antusias sekali terkait materi perdagangan orang yang disampaikan oleh narasumber.

\section{Saran}

a. Sosialisasi atau penyuluhan perihal tindak pidana perdagangan orang harus berkelanjutan.

b. Pemerintah harus lebih aktif lagi dalam melakukan pencegahan dan penanggulangan perihal tindak pidana perdagangan orang.

c. Bukan hanya tanggung jawab/ peran aktif pemerintah saja, tetapi masyarakatpun memiliki tanggung jawab dalam upaya pencegahan terjadinya perdagangan orang dan ikut menangani korban perdagangan orang tersebut.

\section{UCAPAN TERIMA KASIH}

Penulis ucapkan banyak terima kasih kepada Rektor Universitas Suryakancana atas segala support yang diberikan, dan tak lupa kepada Pihak-Pihak Sekolah Khususnya SMA Cianjur Selatan, Cianjur Kota (SMANSA Cianjur) dan Cianjur Utara (SMKN I Pacet) pada Bulan Maret 2016.

\section{DAFTAR PUSTAKA}

\section{A. Buku}

Arif Gosita, (2004), Masalah Korban Kejahatan (Kumpulan Karangan), Jakarta, Bhuana Ilmu Populer Kelompok Gramedia.

Dedi Mulyadi, (2012), Kebijakan Legislasi tentang Sanksi Pidana Pemilu Legislatif di Indonesia dalam Perspektif Demokrasi, Jakarta, Gramata Publishing.

Henny Nuraeny, (2011), Kebijakan Hukum Pidana terhadap Pencegahan Tindak Pidana 
Perdagangan Orang, Jakarta, Sinar Grafika.

L.M. Gandhi Lapian dan Hetty A. Geru, (2006), Trafficking Perempuan dan Anak Penanggulangan Komprehensif Studi Kasus: Sulawesi Utara, Keria sama Yayasan Obor, Convention Watch, Jakarta, Pusat Kajian Perempuan Universitas Indonesia, dan NZAID.

Lilik Mulyadi, (2007), Pembalikan Beban Pembuktian Tindak Pidana Korupsi, Alumni, Bandung.

Satya Arinanto \& Ninuk Triyani (Ed), (2009), Memahami Hukum Dari Konstruksi Sampai Implementasi, Jakarta, Raja Grafindo Persada.

T. Subarsyah Sumadikara, (2010), Penegakan Hukum (Sebuah Pendekatan Politik Hukum dan
Politik Kriminal), TT, Kencana Utama.

\section{B. Peraturan Undangan}

\section{Perundang-}

Undang-Undang Dasar 1945.

Undang-Undang Nomor 21 Tahun 2007 tentang Pemberantasan Tindak Pidana Perdagangan Orang.

\section{Karya Pengabdian Lepas (Website)}

Wikipedia Bahasa Indonesia, diunduh tanggal 18 Agustus 2015.

Program kerja dan kegiatan gugus tugas berdasarkan PERMENKO Bidang kesejahteraan Rakyat No.

25/KEP/MENKO/KESRA/IX/2 009. 
Henny Nuraeni

Journal of Empowerment

Vol. 1, No. 1, Juni 2017 